\title{
優良田園住宅促進法を活用した市街化調整区域における 住宅地開発に関する研究
}

A STUDY ON THE HOUSING DEVELOPMENT UTILIZING THE QUALITY RURAL RESIDENTIAL PROMOTION LAW IN THE URBANIZATION CONTROL AREA

\author{
田嶋麻美*, 鵤 心治**, 小林剛士*** \\ Asami TAJIMA, Shinji IKARUGA and Takeshi KOBAYASHI
}

\begin{abstract}
The purpose of this paper is to clarify effectiveness of the Quality Rural Residential Promotion Law for the land use control technique at the suburbs.

At first, we arranged the operative situation of the law and its characteristic. Next, we arranged a basic policy to institute before the Quality Rural Residence is built from examples of 39 municipalities which had operated the law, and we analyzed these characteristic. Moreover, we selected 4 cities has construction plan in the Urbanization Control Area as a case study, and hearing these cities. From these results, we considered about the ideal operative measure of the law as the development application for the Urbanization Control Area.
\end{abstract}

Keywords : Quality Rural Residence, Housing Development, Urbanization Control Area, Development Permission 優良田園住宅，住宅地開発，市街化調整区域，開発許可

\section{1.はじめに}

\section{1 研究の背景と目的}

高度経済成長期以降、無秩序な市街地の外延化やスプロール現象 が進行し、田園部では営農環境の悪化や耕作放棄地の増加等の問題 が起こっている。都市郊外部におけるこれらの問題に対して、地区 計画、集落地区計画、開発許可制度、特定用途制限地域等各種土地 利用コントロール手法の制度が創設され、スプロールに対応した土 地利用コントロールが行われるようになった ${ }^{1), 2)}$ 。一方で、ライフ スタイルの多様化や既存集落のコミュニティ維持、農業衰退に伴う 活力維持という背景から郊外田園部の住宅立地に対するニーズも増 加しつつある。このような地域で一定水淮の宅地開発を許容するた め、1998 年に「優良田園住宅の建設の促進に関する法律（以下、優 良田園住宅促進法)」が制定された。制度の運用については、法によ り規制項目の枠組みが定められている。

郊外部の住宅地開発では、既存集落や田園環境と共存した全体的 な土地利用コントロールを実現するため、新規開発については一定 のコントロールが行われる。しかし、優良田園住宅促進法の具体的 な運用や判断は各市町村に委㸚られており、既存の土地利用コント ロール手法との整合性や土地利用コントロール手法としての位置づ け、法の目的と合致した運用が行われているかといった点は明らか でない。
そこで、本研究では、全国の優良田園住宅促進法の運用状況とそ の特徴を整理し、特に市街化調整区域における適用事例をもとに、 郊外部の土地利用コントロールに対する同法の有効性と課題を明ら かにするとともに、その結果を踏まえ、活用方策に関する知見を得 ることを目的とする。

\section{2 既往の研究}

優良田園住宅促進法に関する既往研究を表 1 にまとめる。千石ら 3) は、法施行後の初動期に、当時の北海道内の活用事例から、郊外 部の課題に対応した優良田園住宅促進法の活用方策を明らかにして (る。逢見ら ${ }^{4)}$ 、清水ら ${ }^{5)}$ は、それぞれ住民参加型事業の事例を対 象に、手法の有効性について分析している。しかし、全国の事例を 対象に同法の運用状況を整理し、郊外部の他の土地利用コントロー ル手法との関係性を指摘したものはない。

これらの既往研究の内容を踏まえ、本研究では、全国的な制度運 用の動向を明らかにするとともに、区域区分制度を導入している 4 都市を対象に、同法に基づく市街化調整区域の開発実態を調查する。

\section{3 研究の方法}

優良田園住宅促進法の運用に当たっては、市町村が「優良田園住 宅の建設の促進に関する基本方針（以下、基本方針）」を定めること で、優良田園住宅の建設が可能になる 注1)。この基本方針を定める際 には、予め都道府県知事との協議が必要となる。

\footnotetext{
* (侏地域計画連合 工修

** 山口大学大学院理工学研究科 教授. 工博

*** 山口大学大学院理工学研究科 助教・博士 (工学)
} 
研究の方法として、まず、同法を運用している全 39 市町村 (2009 年 4 月 1 日時点）の運用状況について整理し、特徽を考察した。次 に、基本方針の内容について収集、整理し、特徵を考察した。続い て、運用状況の特徴を踏まえ、市街化調整区域における建設計画を 持つ市町村から、既往研究では取り扱われていない新潟県旧新津市 (現新潟市秋葉区 : 以下、新津市)、福井県福井市、岡山県玉野市、
長崎県佐世保市を対象として抽出し、ヒアリング調查注2)を行い、制 度導入の背景を郊外部の土地利用に対する考え方、他の土地利用二 ントロール手法の運用状況と併せて整理した。具体的には、市街化 調整区域における本制度の運用方針に関しては、(1)制度適用の背景、 (2)促進区域と適用区域、(3)開発許可の取り扱いの 3 点から、空間整 備の状況に関しては、(1)建築規制、(2)開発区域の計画概要、(3)既存

表 1 既往研究

\begin{tabular}{|c|c|c|c|}
\hline 既往研究 & 調査対象 & 研究概要 & 知見 \\
\hline $\begin{array}{r}\text { 千石 達也, 松岡 佳秀 } \\
\text { 瀬戸口 剛, 小林 英嗣 } \\
\text { (日本建築学会技術報告集, 2001) }\end{array}$ & $\begin{array}{l}\text { 北海道内の5市町 } \\
\text { ·旭川市 } \\
\text { ·帯広市 (原案策定) } \\
\text { ·由仁町 } \\
\text { ·東川町 } \\
\text { ·二セコ町 }\end{array}$ & $\begin{array}{l}\text { 每道で基本方針を策定済 } \\
5 \text { 市町を対象として、策 }\end{array}$ & $\begin{array}{l}\text { ·良好な田園環境の形成のためには周囲の農村環境に対する視点が不可欠 } \\
\text { である。 } \\
\text { ·それぞれの地域における郊外部の課題に対応し方策が組み立てられており、 } \\
\text { 特に優良田園住宅に関するる針の他に農村環境の保全、農村コミュニティ、 } \\
\text { 郊外部全体の土地利用についての方針を含め、市町村固有の課題に対応 } \\
\text { させて活用されている。 }\end{array}$ \\
\hline $\begin{array}{l}\text { 優良田園住宅法における居住環境の } \\
\text { ンビレッ手法に゙を関する研究: 上越市アーバ } \\
\text { 逢見 まどか, 東 正則 } \\
\text { (農村計画論文集, 2001) }\end{array}$ & $\begin{array}{l}\text { 上越市 } \\
\text { アーバンビレッジ } \\
\text { 第1号地区 }\end{array}$ & $\begin{array}{l}\text { 全国初の事業実施例である新潟県上越市のアーバ } \\
\text { ンビレッシ整備事業について、ユーザー会議のプロ } \\
\text { セスと参加者のユーザー会議に関する評価を分析 } \\
\text { し、ユーザー参加型まちづくり方式の有効性につい } \\
\text { てアンケートを用いて検討している。 }\end{array}$ & 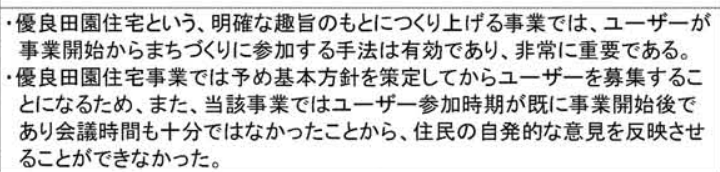 \\
\hline $\begin{array}{r}\text { 地域コミュニティのサステナビリティか } \\
\text { らみた優良田園住宅の計画手法に関 } \\
\text { する課題考察:富山市田園住宅開ヶ丘 } \\
\text { 事業のケーススタディを通して } \\
\text { 清水 郁江, 森 傑 } \\
\text { 都市計画論文集, 2008) }\end{array}$ & $\begin{array}{c}\text { 富山市 } \\
\text { 田園開ヶ丘事業 }\end{array}$ & $\begin{array}{l}\text { NPOが優良田園住宅の供給に積極的·意欲的に取 } \\
\text { り組んでるる富山市田園住宅開ヶ丘事業について、. } \\
\text { 事業の背景と経緯、開発計画、事業費の内訳を整理 } \\
\text { するとともに、住宅地の計画手法を地域コミュニュィ } \\
\text { のサステナビリティの観点から分析したうえで、法の } \\
\text { 目的の実現に向けた計画手法の検討を行っている。 }\end{array}$ & 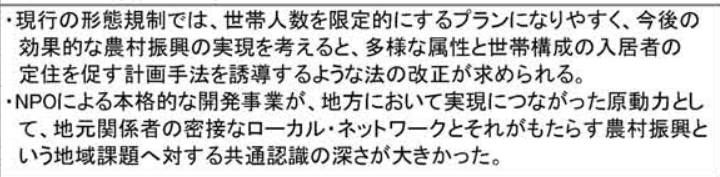 \\
\hline
\end{tabular}

表 2 優良田園住宅促進法の運用状況

\begin{tabular}{|c|c|c|c|c|c|c|c|c|}
\hline & \multirow{2}{*}{$\begin{array}{c}\text { 策定市町村 } \\
\text { ()内は合併前市町村名 }\end{array}$} & \multirow{2}{*}{ 区域区分 } & \multirow{2}{*}{\begin{tabular}{c|} 
基本方針 \\
策定年月日 \\
\end{tabular}} & \multicolumn{5}{|c|}{ 建設計画 } \\
\hline & & & & 認定年月日 & 都市計画区域 & 区画数(開発面積) & 地区計画 & 事業主体 \\
\hline \multirow[t]{9}{*}{ 北海道 } & 東川町 & 都市計画区域外 & $H 11.12 .28$ & $\mathrm{H} 12.7 .28 \sim$ & 都市計画区域外 & $16\left(19,770 \mathrm{~m}^{2}\right), 35\left(37.630 \mathrm{~m}^{2}\right)$ & - & 民間 \\
\hline & 由仁町 & 都市計画区域外 & H12.2.18 & H13.9.18 & 都市計画区域外 & $8\left(25,320 \mathrm{~m}^{2}\right), 19\left(37,630 \mathrm{~m}^{2}\right), 26\left(46,000 \mathrm{~m}^{2}\right)$ & - & 公社, 町, 民間 \\
\hline & 二セコ町 & 都市計画区域外 & H12.7.26 & & & & & \\
\hline & 旭川市 & 線引き & H13.4.1 & $\mathrm{H} 14.7 .23$ & 市街化調整区域 & $11\left(11,800 \mathrm{~m}^{2}\right)$ & 有 & 民間 \\
\hline & 美唄市 & 非線引き & H14.6.28 & & & & & \\
\hline & 当別町 & 非線引き & H15.12.10 & H16.6.24 & 用途白地地域 & $10\left(75,025 \mathrm{~m}^{2}\right)$ & 無 & 民間 \\
\hline & 滝川市 & 非線引き & H17.7.28 & & & & & \\
\hline & 登別市 & 線引き & H19.1.26 & H19.9.12 & 市街化調整区域 & $22\left(18,290 \mathrm{~m}^{3}\right)$ & 有 & 民間 \\
\hline & 上士幌町 & 都市計画区域外 & H20.3.31 & H20.6.30 & 都市計画区域外 & 個別認定 $1\left(2.630 \mathrm{~m}^{2}\right)$ & - & 個人 \\
\hline 岩手県 & 盛岡市 & 線引き & H15.12.26 & & & & & \\
\hline \multirow[t]{2}{*}{ 宮城県 } & 柴田町 & 非線引き & H11.10.29 & H12.3.28 & 都市計画区域外 & $40\left(30.700 \mathrm{~m}^{2}\right)$ & - & 民間 \\
\hline & 松島町 & 線引き & H12.4.1 & & & & & \\
\hline \multirow[t]{4}{*}{ 山形県 } & 山形市 & 線引き & H13.10.2 & H14.9.12 & 市街化調整区域 & $10\left(5,396 \mathrm{~m}^{\prime}\right), 7\left(4,022 \mathrm{~m}^{2}\right)$ & 有 & 民間 \\
\hline & 天童市 & 線引き & H15.5.1 & $\mathrm{H} 16.2 .5$ & 市街化調整区域 & $\begin{array}{l}7\left(4,022 \mathrm{~m}^{3}\right), 6\left(2,508 \mathrm{~m}^{3}\right), 4\left(1,321 \mathrm{~m}^{\prime}\right), 10\left(4,503 \mathrm{~m}^{\prime}\right) \text {, } \\
\text { 個別認定 } 39\end{array}$ & 有 & 民間 \\
\hline & 鶴岡市 & 非線引き & H17.4.8 & & & & & \\
\hline & 上山市 & 線引き & H19.11.12 & $\mathrm{H} 20.11 .14$ & 市街化調整区域 & 個別認定 $1\left(300 \mathrm{~m}^{2}\right)$ & 無 & 個人 \\
\hline 福島県 & 福島市(飯野町) & 都市計画区域外 & $\mathrm{H} 13.6 .8$ & & & & & \\
\hline 茨城県 & かすみがうら市(霞ヶ浦町) & 線引き & H13.3.30 & & & & & \\
\hline \multirow[t]{3}{*}{ 新潟県 } & 上越市 & 線引き & H11.6.8 & $\mathrm{H} 13.2 .23 \sim$ & 市街化調整区域 & $57\left(60,481 \mathrm{~m}^{2}\right), 32\left(23,802 \mathrm{~m}^{\prime}\right)$ & 有 & 公社, 民間 \\
\hline & 新潟市(新津市) & 線引き & H14.12.2 & H17.6 & 市街化調整区域 & $22\left(9,800 \mathrm{~m}^{2}\right)$ & 有 & 民間 \\
\hline & 見附市 & 線引き & H19.11.12 & & & & & \\
\hline 富山県 & 富山市 & 線引き & H15.7.1 & H18.6.15 & 市街化調整区域 & $27\left(21,202 m^{2}\right)$ & 有 & 民間 \\
\hline 福井県 & 福井市 & 線引き & H11.10.1 & $H 12.5 .23$ & 市街化調整区域 & $10\left(9.019 \mathrm{~m}^{\prime}\right)$ & 有 & 民間 \\
\hline 三重県 & 多気町（勢和村） & 都市計画区域外 & H12.12.28 & & & & & \\
\hline 滋賀県 & 近江八幡市 & 線引き & $\mathrm{H} 21.4 .1$ & & & & & \\
\hline 兵庫県 & 丹波市(青垣町) & 都市計画区域外 & H15.3.31 & & & & & \\
\hline 鳥取県 & 智頭町 & 非線引き & H12.3.31 & & & & & \\
\hline 島根県 & 邑南町(石見町) & 都市計画区域外 & H13.4.1 & H18.10.1 & 都市計画区域外 & $52\left(77,107 \mathrm{~m}^{2}\right)$ & - & 民間 \\
\hline 岡山県 & 玉野市 & 線引き & H16.7.1 & H18.11.20 & 市街化調整区域 & $23\left(11,114 \mathrm{~m}^{2}\right)$ & 有 & 民間 \\
\hline 広島県 & 北広島町 (豊平町) & 都市計画区域外 & H14.9.24 & & & & & \\
\hline 香川県 & 高松市 & 線引き & H13.2.22 & & & & & \\
\hline \multirow[t]{2}{*}{ 愛媛県 } & 松山市 & 線引き & H14.4.1 & & & & & \\
\hline & 今治市 & 線引き & H16.5.14 & & & & & \\
\hline 福岡県 & 志摩町 & 線引き & H16.9.16 & & & & & \\
\hline 長崎県 & 佐世保市 & 線引き & H16.3.3 & H18.2.22 & 市街化調整区域 & $9\left(5,700 \mathrm{~m}^{\prime}\right)$ & 有 & 民間 \\
\hline 鹿児島県 & 鹿児島市 & 線引き & H14.3.18 & $\mathrm{H} 14.7 .15 \sim$ & 市街化調整区域 & 個別認定74(300 1,652m') & & 各個人 \\
\hline
\end{tabular}


集落との関係の 3 点から整理した。さらに、上記 4 都市に加え、同 法制定後、モデル的に事業実施が行われた上越市の事例を法の本来 的な活用方法と位置付け、開発事例の整備内容も含めて考察し、制 度の運用段階の課題の指摘を行う。最後に、優良田園住宅制度の位 置づけと市街化調整区域における活用方策を考察する。

なお、現在の北海道内の事例全ては既往研究で取り扱われていな いが、市町村が道との協議を経て策定した基本方針がベースとなる ことから、道全体で同様の傾向となることが予測されるため、事例 調查の対象外とする。その他市街化調整区域における事例のうち、 既往研究で取り扱われていないものであり、かつ、調查協力が得ら れた自治体の事例を対象とし、傾向を分析するものとした。また、 1 宅地毎に開発された優良田園住宅を「個別認定」とし、まとまり のある計画的な一団の開発ではないことから、調査対象外とした。

\section{2. 優良田園住宅促進法の運用状況}

\section{1 制度の概要}

優良田園住宅促進法は、農山村地域、都市の近郊等における優良 な住宅の建設を促進するための措置を講ずることにより、健康的で ゆとりのある国民生活の確保を図ることを目的としている。基本方 針を作成することで、一定の要件に該当する住宅の建設に関する計 画の認定を行うという枠組みを用意し、国・地方公共団体において、 開発許可や農地転用許可の配慮、助成金制度等によりこれを支援す るものである。

\section{2 運用状況の特徵}

全国の優良田園住宅促進法の運用状況を表 2 に示す。同法を運用 している市町村は、北海道、東北、北陸地方に多く、特に、基本方 針の策定、建設計画の認定ともに、北海道が多い。

建設計画について、区域区分の運用の有無からみると、線引き市 町村であり、市街化調整区域における建設計画を認定した市町村が 13 市 $(65 \%)$ と最も多い。非線引き市町村では、用途白地地域におけ る個別開発に対して建設計画を認定した市町村が 1 町、都市計画区 域外における一団の開発の建設計画を認定した市町村が 2 町ある。 都市計画区域外の市町村では、建設計画を認定した市町村は 4 町で ある。これより、主に市街化調整区域と都市計画区域外での開発に 制度が使われていることが分かる。市街化調整区域の一団の開発で は、16 件中 13 件の区域が地区計画制度を用いて開発許可を得てい る。都市計画区域外の開発に比べ開発規模が小さく、都市型の宅地 開発の傾向が強いといえる。東川町、由仁町、山形市、天童市、上 越市、鹿児島市では複数の建設計画を認定している。このうち、東 川町、由仁町の開発区域はそれぞれ隣接または近接しており、上越 市の計画は同一施策に関連付けられたものである。

事業主体をみると、個人の申請による計画を除く 25 件中 22 件が 民間業者である。由仁町、上越市の公社・町による開発、当別町、 富山市の民間業者による開発では戸建コーポラティブ方式を用いて 宅地供給を行っている。

\section{3. 各市町村の運用内容}

基本方針に掲げる事項は法により定められており、以下の $5 つ の$ 内容から構成される。

(1)優良田園住宅の建設の促進に関する基本的な方向
（以下、「基本的な方向」）

(2)優良田園住宅の建設が基本的に適当と認められるおおよその土地 の区域に関する事項（以下、「促進区域」）

(3)優良田園住宅が建設される地域における個性豊かな地域社会の創 造のために必要な事項（以下、「必要事項」）

(4)自然環境の保全との調和、農林漁業の健全な発展との調和その他 優良田園住宅の建設の促進に際し配慮すべき事項

（以下、「配慮事項等」）

(5)その他必要な事項

「基本的な方向」は各市町村の同法運用に至る経緯と制度活用の 方針、「促進区域」「必要事項」は空間的な規定、「配慮事項等」は 周辺環境との調整に関する規定である。

\section{1 基本方針にみる背景と目的}

基本方針では、「基本的な方向」の項目において、基本方針策定に 至る背景、目的、優良田園住宅の需要者像及び住宅像が述べられる。 これらの集計結果を表 3 に示す。

背景に関しては、24 市町村が「価値観の多様化」、21 市町村が「豊 かな自然」18 市町村が「少子高龄化」、17 市町村が「農業後継者の 減少」の項目を挙げている。目的に関しては、25 市町村が「定住の 促進」、16 市町村が「地域の振興」、15 市町村が「自然共生住宅の提 供」の項目を挙げている。需要者像及び住宅像に関しては、33 市町 村が「田園通勤型」、32 市町村が「リタイアライフ型」 21 市町村が

「U I J ターン型」、「自然遊住型」の項目を挙げている。これより、 運用市町村は一般的に、移住の受け入れも視野に入れた、地域の活 性化を主な目的としていることが分かる。

また、背景に関しては、3 市町村が「個別開発・ミニ開発」、1市 町村が「沿道の店舗立地」、目的に関しては 13 市町村が「自然環境

表 3 基本的な方向

\begin{tabular}{|c|c|c|}
\hline & 主な項目 & 市町村数 \\
\hline \multirow{19}{*}{$\begin{array}{l}\text { 背 } \\
\text { 景 }\end{array}$} & 人口增 & \\
\hline & 過疎化 & 13 \\
\hline & 少子高囹化 & 18 \\
\hline & 児童数減少 & \\
\hline & 核家族化 & \\
\hline & 都市部への人口流出 & 10 \\
\hline & 農䊬従事者の高夦化 & 10 \\
\hline & 農業後継者の減少 & 17 \\
\hline & 潜在的な離農希望者の增加 & \\
\hline & 未利用地の增加 & \\
\hline & 生産調整 & \\
\hline & 沿道の店铺立地 & \\
\hline & 個別開発・ミ三開発 & \\
\hline & 価値钼の多様化 & 24 \\
\hline & 農業資産 & \\
\hline & 豊かな自然 & \\
\hline & 田園景䶊 & \\
\hline & 都市機能の充実 & \\
\hline & 钼光資源 & \\
\hline \multirow{12}{*}{$\begin{array}{l}\text { 目 } \\
\text { 的 }\end{array}$} & 自然共生住宅の提供 & 15 \\
\hline & 定住の促進 & 25 \\
\hline & 自然交流等中とりある生活 & 12 \\
\hline & 地域住民との交流 & \\
\hline & 地域の振興 & \\
\hline & 地域農業の活性化 & \\
\hline & 末利用地の有効活用 & \\
\hline & 地域コミュニティ維持・活性化 & \\
\hline & コミュニティつくくり & 12 \\
\hline & 自然環境の保全 & 13 \\
\hline & 個性的な社会構築 & \\
\hline & 市全体の活性化 & \\
\hline \multirow{10}{*}{$\begin{array}{l}\text { 需 } \\
\text { 要 } \\
\text { 像 } \\
\text { 及 } \\
\text { 住 } \\
\text { 像 } \\
\text { 家 }\end{array}$} & 田園通勤型（通勤・通学・買い物などの利便性を享受しながら田園環境を楽しむ） & \\
\hline & リタイアライフ型(退職後の生活を田園嚗境で過ごす） & 32 \\
\hline & し1コターン型(都市の喧騒を離れ、ゆとりある暮らしや自然の中での生活を行う) & \\
\hline & 自然遊住型(自然と同化した生活を送るための住宅) & \\
\hline & SOHO型（情報通信機器などを利用し良好な環境の中で仕事を行う） & \\
\hline & 地域資源活用型（農菜への就業等地域資源を活用した生産活動を行う） & \\
\hline & 教育・健康型(家族の健康や子供の教育のために豊かな自然環境を求めて移住） & \\
\hline & 芸術型(自然環境豊かな㻴境の中で創造性のある活動を行う) & \\
\hline & 地元建替え型(地元住民が優良田園住宅への建替えを行う) & \\
\hline & 一時滞在型 (週末滞在、セカンドハウス等) & \\
\hline
\end{tabular}


の保全」の項目を挙げていることから、これらの市町村では開発コ ントロールを行う方針も見える。その他、目的に関しては 14 市町村 が「地域住民との交流」、7 市町村が「地域コミュニティ維持・活性 化」、12 市町村が「コミュニティづくり」の項目を挙げていること から、本制度をコミュニティ形成までを果たす手法として設定して いることが分かる。

\section{2 各市町村の促進区域}

「促進区域」は、「優良田園住宅の建設を許容するおおよそのゾー

表 4 促進区域の設定理由

\begin{tabular}{|c|c|c|}
\hline 運用方法 & 市町村 & 区域の選定理由 \\
\hline \multirow{7}{*}{$\begin{array}{l}\text { 「区域」 } \\
\text { を指定 }\end{array}$} & 由仁町 & 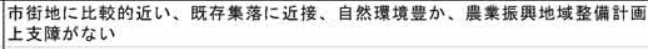 \\
\hline & 柴田町 & 記馢なし \\
\hline & 山形市 & 市街化調整区域内で人口減少 \\
\hline & 邑南町 & 交通と景钼に惠まれた地域である \\
\hline & 北広島町 (旄) & 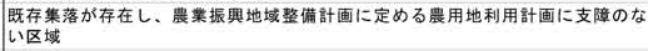 \\
\hline & 北広島町（大） & 生活基盤が擎備されており、自然環境豊かである \\
\hline & 世羅町 & 主要道路に近接、既存集落に绦接、地域への貢献が可能 \\
\hline \multirow{11}{*}{$\begin{array}{l}\text { 「区域」 } \\
\text { 「件】 } \\
\text { を指定 }\end{array}$} & 東川町 & 記戥なし \\
\hline & 当別町 & 記諓なし \\
\hline & 玉野市 & 記载なし \\
\hline & 上士靦町 & 記载なし \\
\hline & 盃岡市 & 市街化調整区域内で人口減少 \\
\hline & 鹤周市 & 記戥なし \\
\hline & 上山市 & 記桟なし \\
\hline & 福島市 & 記戎なし \\
\hline & かすみがうら市 & 記載なし \\
\hline & 多気町 & 記載なし \\
\hline & 青填町 & 農業集落を活性化する楽農住宅地を㓣出するため \\
\hline
\end{tabular}

表 5 促進区域の要件

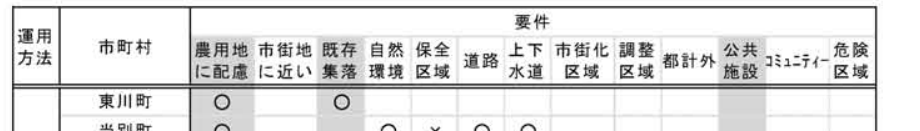

\begin{tabular}{|c|c|c|c|c|c|c|c|c|c|c|c|c|c|}
\hline \multirow{3}{*}{ 区 } & 当別町 & 0 & & & 0 & $x$ & 0 & 0 & & & & & \\
\hline & 王野市 & 0 & & 0 & & & & & & & & & \\
\hline & 上土蜆町 & 0 & & & 0 & $x$ & 0 & 0 & & & & & \\
\hline & 䘝岡市 & 0 & $x$ & & & $x$ & & & & & & 0 & $x$ \\
\hline & 鹳岡市 & 0 & & 0 & 0 & & & & & 0 & 0 & 0 & \\
\hline & 上山市 & 0 & $x$ & 0 & 0 & & & & $x$ & & & 0 & $x$ \\
\hline & 福島市 & 0 & & 0 & 0 & & 0 & & & & & 0 & \\
\hline & かすみがうら市 & 0 & & & 0 & & & & & 0 & & 0 & \\
\hline & 多気町 & & & 0 & & & & & & & & & \\
\hline
\end{tabular}

\begin{tabular}{|c|c|c|c|c|c|c|c|c|c|c|c|c|c|c|}
\hline & 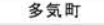 & \multirow[b]{2}{*}{0} & & \multicolumn{3}{|l|}{0} & & & & & & \multirow[b]{2}{*}{0} & \multirow[b]{2}{*}{0} & \\
\hline & 丹波市 & & & 0 & & & 0 & & & & & & & \\
\hline \multirow{21}{*}{ 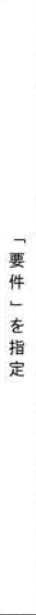 } & 二セコ町 & 0 & & & & & 0 & 0 & & & & & & \\
\hline & 旭川市 & 0 & $x$ & 0 & & $x$ & & & & & & 0 & & $x$ \\
\hline & 美唄市 & 0 & & 0 & & $x$ & 0 & & 0 & & & & & \\
\hline & 伊逢市 & 0 & $x$ & & 0 & $x$ & & & & & $x$ & 0 & & $x$ \\
\hline & 滝川市 & 0 & & & 0 & & & & & & & & 0 & \\
\hline & 登別市 & 0 & $x$ & & 0 & $x$ & 0 & & & & & 0 & & $x$ \\
\hline & 昖岛町 & & & 0 & & & 0 & & & 0 & & & & \\
\hline & 天童市 & 0 & $x$ & 0 & & $x$ & 0 & 0 & & & & 0 & & $x$ \\
\hline & 上越市 & & & 0 & & & & & & 0 & & & & \\
\hline & 新渴市 & 0 & 0 & 0 & 0 & & 0 & 0 & $x$ & & & 0 & 0 & \\
\hline & 見附市 & 0 & & 0 & & $x$ & & & $x$ & & & 0 & & \\
\hline & 畐山市 & & & 0 & 0 & & 0 & 0 & & 0 & & 0 & & \\
\hline & 福井市 & 0 & & 0 & & & & & & & & 0 & & \\
\hline & 近江八㻔市 & 0 & & 0 & 0 & & 0 & & & 0 & & 0 & & \\
\hline & 智頭町 & & & 0 & & & & & & & & & & \\
\hline & 高松市 & 0 & & 0 & & $x$ & & & & & & 0 & & \\
\hline & 松山市 & 0 & & 0 & 0 & $x$ & & & & & & 0 & & \\
\hline & 今治市 & 0 & & 0 & & $x$ & & & & & & & & \\
\hline & 佐世保市 & 0 & & 0 & & $x$ & & & & & & 0 & & \\
\hline & 志摩町 & & & 0 & & & 0 & & & 0 & & & & \\
\hline & 鹿児島市 & 0 & & 0 & & $\times$ & 0 & & & & & & & \\
\hline
\end{tabular}

農用地に配慮 農業振興地域農用地および農地の集団性を損なうような地区は除外する。

市街地に近い都市計画法に基つく市街化区域及ひ市街化区域に隣接する区域。

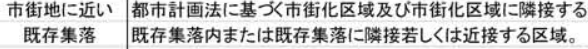

自然環境既存の良好な自然環境を形成している地域。また、その自然環境を保全·活用し、一体的な居 住環境の形成を図ることが可能な地域。

保全区域自然環境を保全すべき地域等。

道路道路が整備されていること。または、住宅の数地が既設の道路に接していること。

上下水道上下水道が整犕されていること。

市街化区域市街化区域であること。

調整区域市街化調整区域であること。

都計外都市計画区域外。

公共施設公共施設が良好な社会生活を営むに足りる水準で整備されていること。

コミュニティー 新たな定住者を受け入れる体制が組織がされ、良好なコミュニティが形成できる区域 危険区域災害危険区域
ンを示すことで、あらかじめ行政が市場にアナウンスする」 ${ }^{6)}$ とい う目的で設定される。具体的な開発の可否の判断は、建設計画の審 査段階で行われる。促進区域についての各市町村の設定方法は以下 の 3 つに分類できる。

（1）市町村が「区域」を指定し、その区域内全てを促進区域とする 場合 (7 市町村)

(2) 市町村が「区域」に加えて「要件」を提示し、両方に適合する 区域を促進区域とする場合（11市町村）

(3) 市町村が「要件」のみを提示し、この要件を満たす区域を促進 区域とする場合（21 市町村）

区域を設定している市町村の設定理由を表 4 に、要件を設定して いる市町村の要件を表 5 に整理する。

区域の設定理由を記載している市町村のうち、3 町が既存集落の 存在を理由としており、2 市が市街化調整区域の人口減少を理由と している。要件については、26 市町村が「農用地に配慮」、24 市町 村が「既存集落」、18 市町村が「公共施設等」の項目を挙げている

表 6 敷地面積の最低限度

\begin{tabular}{|c|c|c|c|c|c|c|}
\hline 最低数地面耫 ( $\mathrm{m}^{\prime}$ ) & $\begin{array}{c}\text { 規定値 } \\
300\end{array}$ & 330 & 400 & 500 & $\overrightarrow{600}$ & $\begin{array}{l}\text { 強化 } \\
660\end{array}$ \\
\hline $\begin{array}{c}\text { 合計 } \\
\end{array}$ & 22 & 1 & 2 & 13 & 1 & 1 \\
\hline カテゴリー№. & 0 & 1 & 2 & 3 & 4 & 5 \\
\hline
\end{tabular}

表 7 建物高さの最高限度

\begin{tabular}{|c|c|c|c|c|c|c|}
\hline 高さ制限 & 規定值 & & & & $\longrightarrow$ & 強化 \\
\hline (嘴) & 3 & 3 & 3 & 2 & 2 & 2 \\
\hline (m) & メートル制限なし & $12 \sim 12.5$ & 10 & メートル制限なし & 10 & 7 \\
\hline 合計 & \begin{tabular}{|l|}
12 \\
\end{tabular} & 3 & 20 & \begin{tabular}{|l|}
2 \\
\end{tabular} & 1 & 1 \\
\hline カテデリリーNo. & 0 & 1 & 2 & 3 & 4 & 5 \\
\hline
\end{tabular}

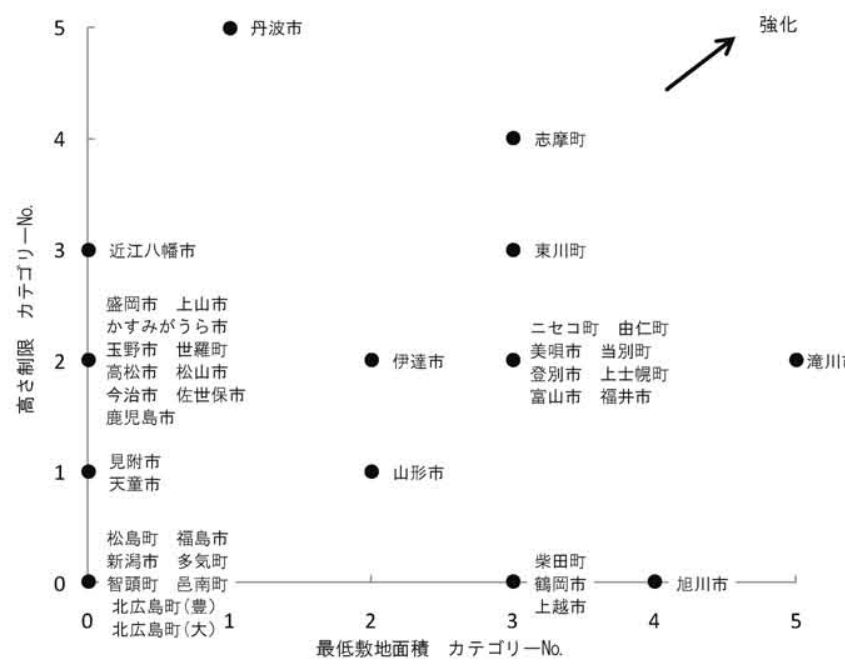

図 1 形態規制

表 8 開発区域の計画

\begin{tabular}{|c|c|c|c|}
\hline & \multirow{5}{*}{ 建設区域の最小規模設定 } & 3,000 $\mathrm{m}^{\prime}$ 以上. 2 4戸のミ二開発の禁止 & 鹿児島市 \\
\hline & & $6.000 \mathrm{~m}$ 以上 & 旭川市，伊達市 \\
\hline & & $10.000 \mathrm{~m}$ 以上 & 富山市 \\
\hline & & $20,000 \mathrm{~m}$ 以上, 10戸以上 & 近江八幡市 \\
\hline & & 10戸以上 & 登別市，王野市 \\
\hline & \multirow{3}{*}{ 建設区域の最大規模設定 } & $20,000 \mathrm{~m}$ 以下 & 旭川市、登別市 \\
\hline & & $50.000 \mathrm{~m}^{2}$ 以下 & 富山市，麓見島市 \\
\hline & & 200,000 m末渾 & 近江八㬝市 \\
\hline & \multirow{2}{*}{ 建設区域の連たん規制 } & 他の建設区域より概ね $1 \mathrm{~km}$ 以上の距離を保つ & 旭川市 \\
\hline & & 同一事莱者による隣接区域の同時着手禁止 & 伊達市 \\
\hline $\begin{array}{l}\text { 開発 } \\
\text { 規模 }\end{array}$ & \multicolumn{2}{|l|}{$6 \mathrm{~m}$ 以上 } & 鹿児島市 \\
\hline \multirow{3}{*}{ 道路 } & \multicolumn{2}{|c|}{ 6m以上，必要に応して幹線道路を配置 } & 近江八幡市 \\
\hline & \multirow{2}{*}{\multicolumn{2}{|c|}{$\begin{array}{l}9.5 \mathrm{~m} \text { 以上. 歩車道の分離 } \\
\text { 主要区画道路 } 9 \mathrm{~m} \text { 、区画道路 } 6 \mathrm{~m} \text {.歩行者専用道路 } 4 \mathrm{~m}\end{array}$}} & 東川町 \\
\hline & & & 霞ヶ浦町 \\
\hline \multirow{4}{*}{$\begin{array}{l}\text { 緑地 } \\
\text { 植载 }\end{array}$} & \multicolumn{2}{|c|}{ 開発区域の緑被率20\%以上 } & 鹿児島市 \\
\hline & \multirow{2}{*}{\multicolumn{2}{|c|}{ 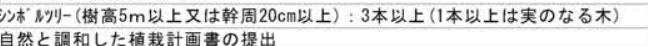 }} & 麇児島市 \\
\hline & & & 柴田町。石見町 \\
\hline & \multicolumn{2}{|c|}{ 10ha以上の開発の場合：「公園等」は開発面積の8\%以上，「公園」は5 $5 \%$ 以 } & 東川町 \\
\hline \multirow{2}{*}{ 公園 } & \multicolumn{2}{|c|}{ 一団の面皘を磼保，既存集落に面した位置に配置 } & 天童市 \\
\hline & \multicolumn{2}{|c|}{ 既存集落とふれあい、地区のコミュニティ形成に資する公園等 } & 霞ヶ浦町 \\
\hline
\end{tabular}


ことから、これらは区域設定の際の一般的な条件といえる。1 市で 「市街地に近い」ことを要件にしているのに対し、6 市では禁止事 項としている。この市街地との距離要件を設定している 7 市は何れ も線引き都市である。その他、14 市町村が「道路」、6 市町村が「上 下水道」と、インフラ整備に関する要件を挙げている。

\section{3 各市町村の規制項目等}

「必要事項」は、「各市町村の地域の個性の発揮、創意工夫を誘導

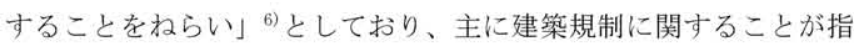
導される。ここでは、法の規定がある建築の規模に関する項目と、 開発区域全体に係る規制項目について整理する。後者については「配 慮事項等」の内容も含む。

（1）建築の規模に関する項目

「敷地面積の限度」(表 6 )、「建蔽率及び容積率」、「高さ制限」（表 7 )について整理する。

「敷地面積の限度」については、法の規定值である最低限度 300 $\mathrm{m}^{2}$ を適応する市町村が 22 市町村と最も多く、次いで $500 \mathrm{~m}^{2}$ 以上に強 化している市町村が 13 市町村と多い。600 m²以上に強化している市 町村、 $660 \mathrm{~m}^{2}$ 以上に強化している市町村がそれぞれ 1 市町村ずつあ り、厳しく運用している市町村もみられる。

「建蔽率及び容積率」の最高限度については、全ての市町村がそ れぞれ 3/10、5/10 以下と規定值のまま運用している。

「高さ制限」については、規定值である「階数 3 以下」をそのま ま適用する市町村が 12 市町村あるが、「階数 3 以下」に「高さの上 限 $10 \mathrm{~m}$ を加えた市町村が 20 市町村と最も多い。4市町では階数そ のものの上限を 2 以下に引き下げ、厳しく規定している。

「敷地面積の限度」と「高さ制限」の 2 つの指標により図化した ものを図 1 に示す。志摩町、東川町において、形態に対する規制が 厳しいといえる。

(2) 開発区域の計画に関する項目

ここでは、面的な開発を前提とした開発区域における規制項目の うち、「開発規模」、「道路の幅員」、「緑地、植栽及び公園」について 整理する (表 8)。

「開発規模」については 7 市で規定を定めており、何れも区域区 分制度を導入している。最小規模については、旭川市と伊達市で開 発面積 6,000 $\mathrm{m}^{2}$ 以上、富山市で $10,000 \mathrm{~m}^{2}$ 以上、登別市、玉野市で 10 戸以上、鹿児島市で $3,000 \mathrm{~m}^{2}$ 以上かつ 5 戸以上、近江八幡市で 20,000 $\mathrm{m}^{2}$ 以上かつ 10 戸以上と指導している。最大規模については 旭川市、登別市で $20,000 \mathrm{~m}^{2}$ 以下、富山市、鹿児島市で $50,000 \mathrm{~m}^{2}$ 以 下、近江八幡市で $200,000 \mathrm{~m}^{2}$ 未満と指導している。また、開発区域 の連たんに関して、旭川市では「他の一団の優良田園住宅の建設区 域より概ね $1 \mathrm{~km}$ 以上の距離を置く」とし、伊達市では「同一事業者 による隣接区域での新たな事業の同時着手の禁止」を指導している。

「道路の幅員」については、近江八幡市、鹿児島市は $6 \mathrm{~m}$ 以上と 規定しており、近江八幡市は区域の規模、周辺状況等必要に応じて 幹線道路を配置することとしている。東川町は $9.5 \mathrm{~m}$ 以上とし、歩 車道の分離を指導している。霞ヶ浦町は、主要区画道路は $9 \mathrm{~m}$ 、区 画道路は $6 \mathrm{~m}$ 、歩行者専用道路は $4 \mathrm{~m}$ と細かく指導している。

「緑地」については、鹿児島市が開発区域の緑被率を $20 \%$ 以上と している。「植栽」については、鹿児島市が「シンボルッリーとして 樹高 $5 \mathrm{~m}$ 以上又は幹周（目通り） $20 \mathrm{~cm}$ 以上の樹木を 3 本以上（1 本
以上は実のなる木）植樹」するよう指導している。柴田町、石見町 は「自然と調和した植栽計画書」の提出を義務づけている。「公園」 については、東川町では、10ha 以上の開発を行う場合、「公園等」 は開発面積の $8 \%$ 以上確保し、そのうち「公園」は $5 \%$ 以上確保するよ う指導している。また、天童市では緑地・公園の設置に関して「一 団の面積を確保するとともに、既存集落に面した位置に配置する」 とし、霞ヶ浦町は公園・広場の設置に関して「既存集落とふれあい、 地区のコミュニティ形成に資する公園等」と指導している。

以上より、開発区域の計画に関する項目については、鹿児島市、 東川町、霞ヶ浦町が厳しく指導しているといえる。但し、鹿児島市 では 2009 年 4 月 1 日時点で認定されている建設計画は全て個人申請 による個別の計画であり、面的な開発は認定されていない。霞ヶ浦 町については、認定された建設計画はない。

\section{4 まとめ}

基本方針は、優良田園住宅の建設促進に当たって、市町村毎に郊 外部の状況をもとにビジョンの設定、行政区域内での宅地整備促進 のための区域設定や開発区域に倸る規制、各住戸に倸る細かな要件 まで総合的に設定することが可能である。

「基本的な方向」では、目的にコミュニティ形成に関する項目が 含まれており、住空間よりも、形成される地域コミュニティや住環 境のビジョンを多く掲げている。

「促進区域」についても、区域設定を行っている市町村の設定理 由にはコミュニティ形成に関する内容が考慮されている。加えて、 要件の設定では、市街地との距離関係やインフラ整備に関する項目 を要件とすることで、散発的な開発、スプロール的な開発、インフ ラコストへの対策を図っていると考えられる。

「必要事項」では、「敷地面積の限度」、高さ制限」については法 の規定值を強化して運用している市町村が多く見られた。各住戸に 係るその他の規制については、建築物の色、主要構造、屋根形態、 壁面の後退距離、垣根の設置、宅地面の利用等についても多くの市 町村で定められている。また、開発区域の位置、規模等に係る項目 は、開発をコントロールする上で重要な要件である。この「開発規 模」を規定している 7 市は何れも線引き市町村であることから、市 街化調整区域での散発的な開発を防ぐことや、まとまりのある宅地 整備を行うことを誘導していると考えられる。

\section{4. 市街化調整区域における本制度の適用事例}

\section{1 市街化調整区域における開発の問題整理と本論の視点}

本制度は、既往研究により、農村地域においてコミュニティ形成 の役割を果たしながら宅地供給を行う手法としての有効性が明らか となっている。これは、3 章 1 節で述べたように、都市計画区域外 等の農山村地域では、同様の効果が得られると考えられる。しかし、 市街地縁辺部における宅地の開発コントロールがどのように行われ ているかは明らかにされていない。基本方針の目的である「自然共 生住宅の提供」や、需要者像の「田園通勤型」等、市街地の利便性 を享受しながら郊外田園部の住環境を形成するにあたっては、如何 に開発コントロールを行っていくかが重要な視点となる。市街地縁 辺部で土地利用上の課題とされるのは、市街化調整区域と非線引き 用途白地地域である。前述の通り、優良田園住宅の認定事例のうち、 一団の開発は市街化調整区域に位置するものが 25 件中 16 件 (64\%)、 
非線引き白地地域で 1 件 (4\%) である。特に件数の多い市街化調整 区域は、開発を抑制すべき方針の区域であるが、都市計画法第 34 条第 11 号や第 34 条第 12 号、第 34 条第 14 号の運用による開発許可 制度のうち、各自治体の条例の内容によっては個別の宅地開発を許 容してしまいスプロールを助長させる点が問題であることが多く指 摘されている77,8),99, 10), 11)。

一方、開発内容の誘導手法としては、第 34 条第 10 号「地区計画 等の内容に適合する開発」がある ${ }^{12)}$ 。優良田園住宅制度は、第 34 条第 11 号のような区域指定も可能であり、かつ、地区計画制度のよ うに開発内容を誘導することも可能であることから、計画的な開発 手法と位置づけることもできる。市街化調整区域においては、既存 の各種土地利用コントロール手法との整合性を図り、目的を持った 秩序ある運用が行われるべきであるため、既往研究で指摘されてい る課題に対して、本制度がどのように有効であるかを明らかにする 必要がある。

以上のことから、本章では、全国の適用事例のうち市街化調整区 域の開発に着目し、既往研究で取り扱われていない新潟県旧新津市、 福井県福井市、岡山県玉野市、長崎県佐世保市について制度運用の 経緯と背景、実施方法、開発内容を調查した（表 10)。また、適切 な事業実施方策について検討するため、市街化調整区域における全 国初の認定事例であり、モデル的に事業実施された新潟県上越市の 事例を優良田園住宅促進法の本来的な活用方法と位置付け、併せて 整理する (表 9 )。

\section{2 新潟県上越市の運用状況 (表 9 参照)}

上越市は基本方針を全国で最初に策定した市であり、第 1 期目の 開発は市の土地開発公社により行われたモデル的な事業である。市 の超長期ビジョンである「のびやか J プラン」の施策の一つとして、 農村地域で定住を促進する「アーバンビレッジ整備事業」を位置づ け、これに基づいて 2 件の建設計画が認定されている。他計画や他 事業と優良田園住宅制度が上手く関連づけられており、県営ほ場整 備事業の創設換地として生み出された非農用地（創設非農用地）を 取得する点が特徵である。特に、1 期目の事業では整備手法として 農村活性化住環境整備事業、販売方式として戸建コーポラティブ方 式を用い、生活環境整備の補助金取得とコミュニティ形成まで全体 的に手掛けた事業である。2 期目は農業協同組合によるもので、コ 一ポラティブ方式は用いていないが、予め「申込資格」が設けられ ている。これは優良田園住宅の分譲地を購入する意義を考慮したも のであり、他市町村の事例に比べ、住民の意識が高いと考えられる。 また、 2 度の基本方針の空間化と申込資格の設定等のノウハウから、 今後民間企業の活力を活用する方向へ移行していく可能性もある。

開発内容については、まとまった土地を取得できたため、比較的 大規模な開発である。特に、1 期目の開発については、農村活性化 住環境整備事業の補助金を活用し、公園や緑地、コミュニティ施設 等、公共空間の整備が進んでいる。上越市では基本方針の中で敷地

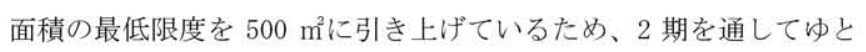
りある住宅地を形成している。

このように上越市では、長期的なビジョンに基づいて段階的な計 画が策定され事業実施が行われており、ビジョンを実現させる一つ の手法として優良田園住宅促進法が活用されている。
4. 3 郊外部の整備と優良田園住宅制度の運用方針（表 10 参照）

(1) 新潟県新津市

(1)制度適用の背景

旧新津市注 ${ }^{3)}$ は、旧新潟市注 3 にに近接し、JR が 3 線乗り入れ、6 駅 を有しているという交通利便性の良さから、市街化区域においては 人口増加傾向であったが、農村部の集落内では人口減少が進んでい た注4)。新津市に似合う住環境づくり、魅力ある居住空間を模索する ため、2000 年度に基本方針の作成と建設区域として設定可能な場所 の調查を行った。

(2)促進区域と適用区域

新津市では、促進区域の要件に「既存の集落内及び集落に隣接す る地域とする。なお、既存集落の形態を大きく変えることがないよ うにする。」とあり、既存住民のコミュニティに影響しない規模での 開発を行う方針である。

北潟地区は、既存集落に隣接、市街化区域に近接しており、整備 方針、促進区域の要件に適合する区域で開発が行われた。既存集落 では高齢化、農業の若い担い手の減少により集落の自治活動の存続 が困難な状態になり、農地を手放したいという意向があった。開発 当時の世帯数が 45 、新たな団地の世帯数が 22 世帯であったため、 自治活動の逆転現象はないという地元の判断もあり、建設が決定さ れた。

表 9 上越市の事業実施方法

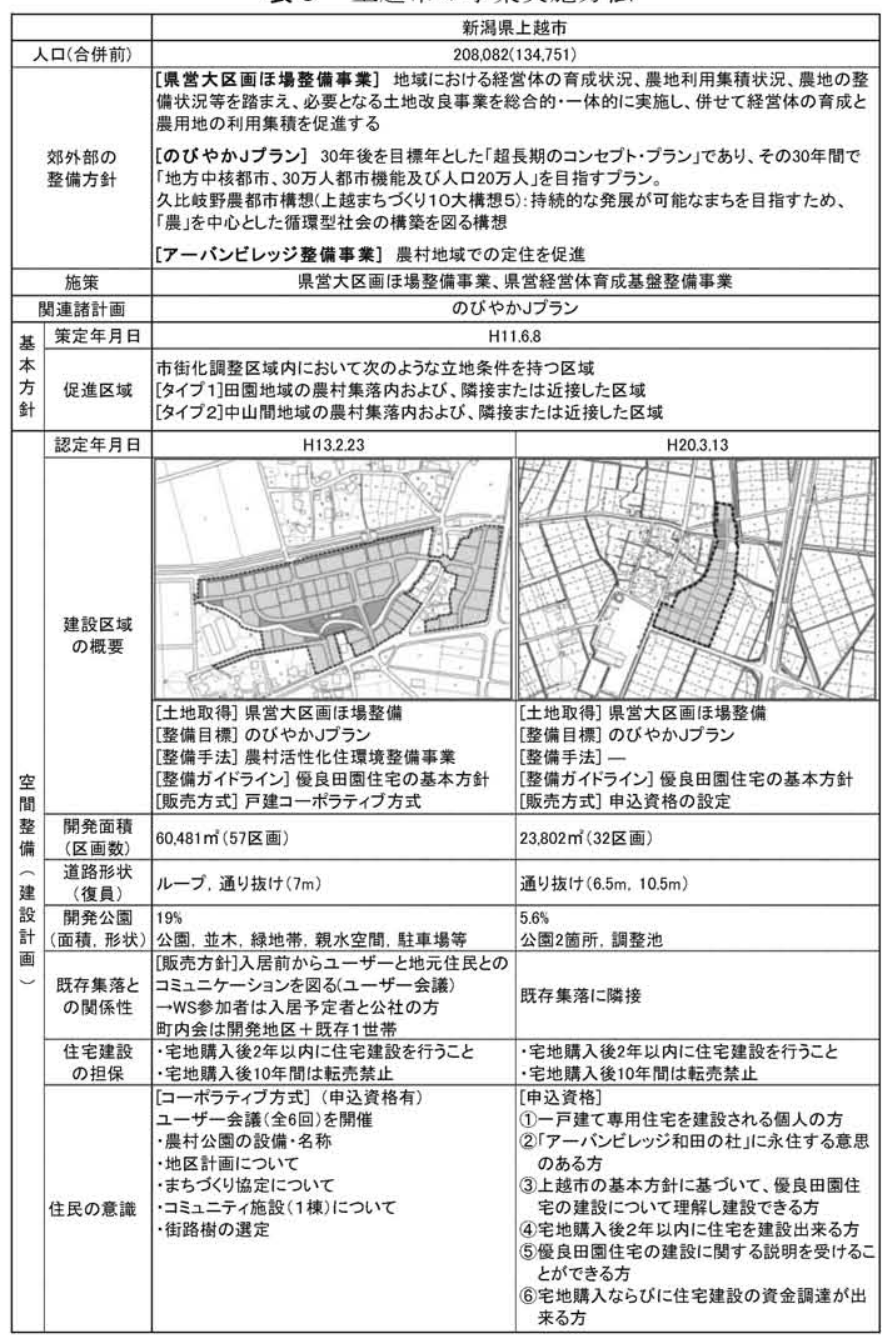


表 10 線引き市町村 4 市の制度運用と事業実施状況

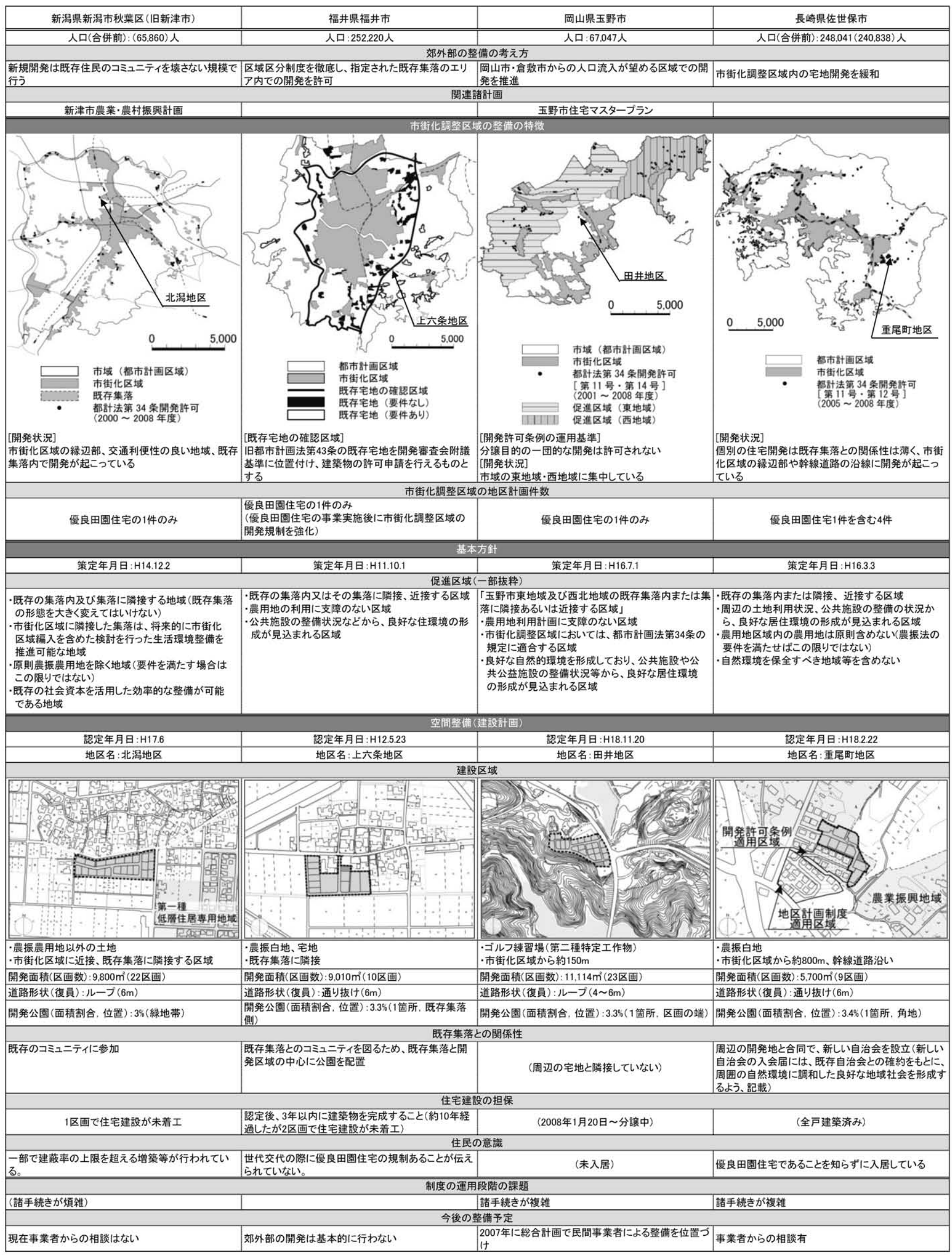


(3)開発許可の取り扱い

新津市では、都市計画法第 34 条第 11 号・第 34 条第 12 号の運用 は行っていない。その他の第 34 条開発許可による開発は市街化区域 の縁辺部や鉄道駅、幹線道路沿線、既存集落縁辺部に集中しており、 平野部の農地はまとまった形で保全されているといえる。

また、優良田園住宅建設による農地転用については、農業・農村 振興計画 $(2004$ 年策定) に建設計画の位置・規模等を盛り込むこと で許可している。

(2) 福井県福井市

\section{(1)制度適用の背景}

福井市は、隣接する永平寺町の一部を含む県内唯一の線引き都市 計画区域をもっており、南北には $2 つ の$ 非線引き都市計画区域が隣 接している。そのため、福井市の市街化調整区域に対する住宅建設 のニーズは周辺市町に流れていた。市街化調整区域内及び農山村地 域の活性化と市内人口の定着を図るため、制度を導入した。

(2)促進区域と適用区域

福井市では、1999 年に基本方針が施行され、2000 年に上六条地区 が地区計画制度を用いて開発された。上六条地区は基本方針の公表 に先行して法の規定による宅地造成が計画されていたが、敷地面積 が基本方針で規定される敷地面積の最低基淮 $500 \mathrm{~m}^{2} に$ 適合しないも のであった。法の規定值を強化して設定した経緯や現状を踏まえた 制度運用を図る一方で、合理的に施策を展開する必要があるため、 1 年以内に限り、法定内で、当該地域の立地条件などを勘案した面 積を適用することとし、認定された。

(3)開発許可の取り扱い

福井市では 2002 年に県の方針により市街化調整区域における地 区計画制度の許可基淮が強化され、2007 年より 3 年をかけて策定中 である都市計画マスタープランの見直しにおいては、市街化調整区 域での地区計画制度の適用は抑制する旨で検討されている。現在は 区域区分制度を徹底し、指定された既存集落のエリア内での開発を 都市計画法旧 43 条により許可することとしている注5)。そのため、 今後優良田園住宅による整備は行わない方針であり、地区計画制度 についても、枠組みは残しているが、現在までに許可されたのは優 良田園住宅の事例 1 件のみである。

(3) 岡山県玉野市

(1)制度適用の背景

玉野市は、政令指定都市である岡山市、倉敷市と隣接しているが、 玉野市の市街化区域は臨海部に偏っており、岡山市・倉敷市からの 宅地需要が見込める東地域及び西北地域は市街化調整区域である。 2001 年に改正都市計画法の開発許可条例の運用が開始されたが、分 譲目的の一団的な開発は規制されていた。そこで、2002 年の住宅マ スタープラン策定時に、重点施策として優良田園住宅の制度導入を 図った。

(2)促進区域と適用区域

住宅マスタープランの策定にあたっては、玉野市民に対して定住 条件、住宅政策一の展望等、岡山、倉敷市民に対して潜在的住宅需 要等のアンケートを実施しており、事業実施に向けて民間業者に対 して優良田園住宅制度導入に向けた意向についてもアンケートを実 施している。この結果を受けて住宅需要のシミュレーションを行い、 岡山市、倉敷市からの人口流入が望める区域を促進区域として設定
している。

田井地区は本来、この促進区域とは異なる区域に位置するが、事 業者が促進区域の拡大に係る要望書を提出し、基本方針の一部変更 が行われたことにより認定された。

(3)開発許可の取り扱い

2001 年に運用が開始された都市計画法第 34 条第 11 号は、敷地相 互間最短距離が「55m以内」、連たん要件が「50戸以上」、用途は「自 己用一戸建て住宅」という要件で運用されている。第 34 条第 11 号、 第 34 条第 14 号による個別の開発は、市域の東地域、西北地域に集 中している。これは優良田園住宅の促進区域と一致しており、区域 設定は開発要求に沿っていることがわかる。

現在の実績は 2006 年に認定された田井地区の 1 件のみであるが、 2007 年には玉野市総合計画に優良田園住宅制度を活用した民間事 業者主体による住宅地整備を位置づけており、今後も活用する方向 である。

（4）長崎県佐世保市

(1)制度適用の背景

佐世保市は地形的に平坦地がそしく、市街化区域も少ない（約 18. 5\%)。市街化調整区域における地域活力の低下、郊外居住の二ー ズの高まり、土地が安価な周辺町への人口流出等の問題を受けて、 市街化調整区域の住宅建設の緩和策を図ることとした。

(2)促進区域と適用区域

優良田園住宅の促進区域は要件のみを提示する設定方法であり、 市街化調整区域全域で建設が可能である。

重尾町地区は、市街化区域から約 $800 \mathrm{~m}$ の距離にあるが、幹線道 路沿いに位置し、高等学校、バス停が近い等の利便性から、開発需 要は高く、周辺も宅地開発が進んでいる。当地区は同業者による地 区計画制度と開発許可条例（旧都市計画法第 34 条 8 号の 3) を用い た開発に連たんしており、農振白地地域のうち、開発許可条例によ って開発できる面積 3,000 m超える連たん先が優良田園住宅制度 を用いて開発された。

(3)開発許可の取り扱い

2003 年に地区計画制度、2004 年に優良田園住宅促進法、2005 年 に開発許可条例（都市計画法第 34 条第 11 号、第 12 号）の運用を開 始し、市街化調整区域全域を対象に土地の特性別に各制度の位置づ けを行った。

優良田園住宅の認定を行うことで農振白地での住宅地開発が可能 となったが、開発許可条例の運用を開始したことで全市的に個別の 住宅開発が増加し、計画的に開発をコントロールできていない状況 に至っている。

\section{4 空間整備について}

(1) 新潟県新津市北潟地区

(1)建築規制について

新津市は基本方針では細部の規定は行っていないが、北潟地区の 地区整備計画では、階数、高さ等を一部強化して運用している。建 築された住宅は、この規定に基づいて整備されているものの、一部 で届け出によらない増築が行われている。

(2)開発区域の計画について

区画道路は幅員 $6 \mathrm{~m}$ の道路がループ状に整備されている。開発公 園については、面積は技術基準の規定值の $3 \%$ であ、接続先道路側 
に緑地帯として設けている。しかし、その管理体制は整っておらず、 開発当初に植えられた低木が枯れた後は、緑地帯に面する区画の住 民が任意で植栽を行っている。

当地区は 2005 年 6 月に建設計画が認定されたが、 1 区画が菜園と して利用されており、未着工である。

(3)既存集落との関係

当地区は既存集落に隣接しており、自治会は既存のコミュニティ に参加している。しかし、住宅建設が行われていない区画があるこ とや、緑地帯の植栽の整備規則が設けられていないことから、土地 購入時に優良田園住宅であることの周知や新津市の基本方針への理 解は得られていないと考えられる。

（2）福井県福井市上六条地区

(1)建築規制について

福井市では、基本方針と上六条地区の地区整備計画をほぼ同等の 内容で運用している。しかし、前述の通り、敷地面積の最低限度に ついては、当該地区に限り基準を緩和している。建築された住宅は、

概ねこの規定を見たしているが、世代交代の際に優良田園住宅の規 制があることの周知が十分でなく、市には建蔽率の上限を超える増 築の相談が寄せられている。

(2)開発区域の計画について

区画道路は幅員 $6 \mathrm{~m}$ の道路が通り抜けの形状で整備されている。 開発公園は既存集落との境界に設け、砂地をフェンスで囲んだもの に遊具を設置している。また、福井市では基本方針において 3 年以 内に建築物を完成するよう指導しているが、認定後約 10 年経過後も 2 戸の住宅建設が未着工である。

(3)既存集落との関係

当地区は既存集落に街区内で隣接し、開発区域には既存宅地 1 区 画を含む。新津市同様、住宅建設が行われていない区画があること から、住民一の優良田園住宅であることの周知や基本方針への理解 は十分でなく、整備目的が達成されていない。

( 3 ） 岡山県玉野市田井地区

(1)建築規制について

玉野市は、敷地面積の最低限度、建蔽率・容積率の最高限度につ いて、優良田園住宅促進法の規定值をそのまま運用しているが、敷 地面積については最高限度を $500 \mathrm{~m}^{2} 、$ 建蔽率については最低限度を $2.2 / 10$ 以上とし、建築規模の範囲を限定している。

基本方針と田井地区の地区整備計画はほぼ同等の内容で運用して おり、地区整備計画では、基本方針の項目について、詳細な整備要 件を加えている。

(2)開発区域の計画について

開発前はゴルフ練習場であり、市街化区域からは約 $150 \mathrm{~m}$ の距離 にある。区画道路は幅員 $4 \mathrm{~m}$ と $6 \mathrm{~m}$ の道路がループ状に整備されてい る。開発公園は区画の端に設け、砂地をフェンスで囲んだものに遊 具を設置している。また、23 区画のうち、3 区画は建売分譲である。 (3)既存集落との関係

2009 年 7 月末日時点では未入居であるが、周辺の宅地と隣接して いないため、単独でコミュニティを形成することになる。

（4）長崎県佐世保市重尾町地区

(1)建築規制について

佐世保市では、基本方針と地区整備計画をほぼ同等の内容で運用
している。優良田園住宅の規定値をそのまま運用し、階数にのみ、 高さ制限が設けられている。開発区域が斜面地であるため、敷地の 一部が法面等に利用され、平面的に利用可能な敷地は若干少なくな っている。

(2)開発区域の計画について

区画道路は幅員 $6 \mathrm{~m}$ の道路が通り抜けの形状で整備されているが、 接続先の一方が私道であるため、制度上は回転広場を設けた袋路で ある。市全域の地形による制約から、斜面地に屈曲した道路が通る 住宅地が形成された。開発公園は、砂地をフェンスで囲んだものを 三角の形状で設置している。

(3)既存集落との関係

自治会は周辺の開発地と合同で新規に結成しているが、既存自治 会との確約をもとに、新しい自治会の入会届には、周囲の自然環境 に調和した良好な地域社会の形成に努めるよう、記載されている。

\section{5 まとめ}

区域区分制度を実施している新津市、福井市、玉野市、佐世保市 の 4 市を調查した結果、制度導入の経緯はそれぞれ異なるが、市街 化調整区域における宅地供給手法として本制度の運用を開始してい る。新津市、福井市では既存集落のコミュニティ維持の目的が強く、 玉野市、佐世保市では市街化調整区域における宅地供給の目的が強 い。市街化調整区域の特性から開発許可を得るためのツールとして のメリットが大きく、玉野市を除く 3 市では促進区域は要件のみを 提示しているため、農業振興地域整備法との調整がつけば、市街化 調整区域全域で建設が可能である。行政側の誘導が無ければ開発要 求に応じた宅地開発が行われる可能性が懸念され、法の目的に合致 した運用とはいえない

福井市では既存の土地利用コントロール手法との調整が図れない ため優良田園住宅制度を活用しない方向にあり、佐世保市では開発 許可条例(都市計画法第 34 条第 11 号、第 12 号)の運用開始により、 宅地供給手法としての優良田園住宅制度の意味が薄れている。また、 4 都市ともに開発許可を得るために地区計画制度を適用しており、 地区計画区域と優良田園住宅の開発区域が一致している。開発需要 に対して規制緩和策として運用しているため、補助金による住環境 等の整備は行われておらず、優良田園住宅としての意味が薄れてい る。

また、制度の運用段階では、基本方針の作成、建設計画の認定時 に県知事との協議や承認を必要とする。許可手続き等が複雑である ため、建設開始までに時間を要しており、宅地供給手法としては敬 遠されている。

開発内容については、基本方針により一定の住環境の質が担保さ れるものの、公共空間についてはその面積、整備状況や管理、使わ れ方等、コミュニティ形成の面では開発区域周辺との関係性や優良 田園住宅への入居にあたっての意識等に、不十分な点がみられる。 また、新津市、福井市、玉野市では区画分譲や住宅建設が適度な期 間で完了していないことから、開発の必要性の把握、一定期間内で の住宅建設の担保が求められる。福井市では基本方針に住宅建設完 了の期限を設けているが、徹底されていない。

上越市の事業ではこれらの点が補助事業や申込資格により補われ ている。開発区域については県営ほ場整備事業と関連付けているた め、行政の意図する区域での開発であり、1 期目については戸建コ 
一ポラティブ手法を用いているため、事業期間は宅地供給のみの期 間ではない。行政が積極的に郊外部の住環境整備や事業に取り組ん でいる成果ではあるが、2 期目についても、民間業者が優良田園住 宅の分譲地ということを入居者に申込段階で十分に理解してもらう 点が特徵的である。他市同様、補助金や市の資金による整備が行え なくても、予め入居者に優良田園住宅の分譲地を購入する意義につ いての共通の理解があるということは、長期的にみても有益である。

\section{5.おわりに}

以下に、本研究で得られた知見をまとめる。

（1）基本方針による規制内容について

本制度は、優良田園住宅の建設に当たって、予め市町村毎にビジ ヨンの設定から各住戸に係る細かな要件までを、基本方針において 総合的に設定することが特徵である。

全国の運用状況では、技術的な基準を設ける際、コミュニティ形 成に関する内容が重視されており、住環境の質が求められているこ とがわかる。

（2）促進区域の設定について

同法の基本理念は、郊外部の環境に合わせた豊かな暮らしを推進 することであり、単なる宅地開発のツールとしてではなく、本来の 法の目的に沿った運用を行うべきである。また、本制度を用いて農 地を宅地化する以上、速やかに開発の目的を達成すべきである。そ のためには、基本方針の整備目的に基づいた適切な促進区域を設定 する必要がある。現在は要件のみを提示する設定方法を用いる市町 村が最も多いが、宅地整備の目的を明確にし、具体的な区域を設定 することが望ましい。

（3）制度の有効性と課題について

既往研究において、本制度を用いて良好な田園住環境を創出する ためには、周辺環境に配慮する視点が必要であること ${ }^{3)}$ 、住民参加 の手法を用いる場合には、事業開始段階からまちづくりに参加する こと ${ }^{4)}$ 、地元関倸者の密接なローカル・ネットワークと地域課題 対する共通認識が重要であること ${ }^{5)}$ が知見として整理されている。

本論文では、郊外部の土地利用コントロールを考慮した場合の本 制度の有効性と課題を指摘した。具体的には、基本方針において、 促進区域や開発規模等の設定により、一定の郊外部の開発コントロ 一ルが可能であることが有効性として指摘できる。しかし、その運 用は各市町村に任されており、市街化調整区域では、地区計画制度 との併用により開発許可を得ているものの、現状では地区計画制度 は開発許可を得るため、優良田園住宅制度は農地転用許可を得るた めの役割に止まっている点においては課題といえよう。福井市、玉 野市、佐世保市ともに、市街化調整区域において優良田園住宅制度 と他の開発手法との整合性が取れておらず、開発需要毎に土地の特 性、開発の規模に見合った制度を用いる傾向が強い。

空間整備については、民間業者は宅地開発を行うために制度を利 用しており、公共空間の整備が十分でない。また、宅地購入者に対 して「優良田園住宅」の周知が十分でなく、住宅建設段階以降の住 環境形成に影響を与えている。

（4）市街化調整区域における今後の活用方策について

基本方針は郊外部全域の住環境整備の考え方を示すものとなり得 ることから、この位置付けを強め郊外部整備のガイドラインとして
機能することが望ましい。

上位計画がなく個別に開発業者に対応した活用方法では、市街化 調整区域や農振白地地域における開発のみを目的とした使い方とな る可能性が高い。このことは優良田園住宅制度に限らず、市街化調 整区域全体としていくつかの開発手法が法的に認められている限り、 それぞれの法の理念を尊重する手法として、適材適所で各手法を用 いるべきである。そのためには、各手法の運用の根拠となる各市町 村の郊外部のマスタープランが必要である。優良田園住宅の基本方 針を市街化調整区域のマスタープランとして位置付け、市町村とし ての目的を明確化し、促進区域設定の際に十分な分析を行うことが、 市街化調整区域の秩序ある計画的な整備方策として有効である。

注

注 1) 優良田園住宅を建設しようとする者は、その建設に関する計画を作成し、 これを市町村に提出して、当該優良田園住宅建設計画が適当である旨の認 定を受けることができる（優良田園住宅促進法第 4 条）。

注 2) ヒアリング調査は、新津市では 2009 年 10 月 23 日、新潟市秋葉区役所 建設課まちづくり係、福井市では 2009 年 10 月 22 日、福井市建設部建築指 導課、都市戦略部都市計画課、玉野市では 2009 年 7 月 22 日、玉野市建設 部都市計画課、佐世保市では 2009 年 7 月 8 日、佐世保市都市整備部都市政 策課を対象に実施した。

注 3) 新潟市は、2005 年に新津市を含む周辺の 14 市町村が合併し、面積約 $726 \mathrm{k}$ $\mathrm{m}^{2}$ 、人口約 81 万 4 千人の政令指定都市となった。

注 4）H7〜H12 都市計画基礎調查: 市街化区域内の人口は $2.0 \%$ 増であったが、 市街化調整区域内の人口は $3.7 \%$ 減であった。

注 5) 2000 年以降の福井市の市街化調整区域の開発手法は、主に都市計画法旧 43 条による既存宅地制度に基づいた開発、第 34 条 14 号による開発、その 他の開発（他 34 条関連等）の 3 パタンである。

\section{参考文献}

1) 鵤心治, 井上聡, 小林剛士, 石村壽浩: 農地転用と都市計画法第 34 条 8 号の 3 による市街化調整区域の開発動向一山口県防府市を事例として一, 日本建築学会計画系論文集, 第 604 号, pp77 84, 2006.6

2）古田朋子, 鵤心治, 小林剛士：「技術基準」に着目した用途白地地域に おける住宅地開発に関する研究一中国, 四国, 九州地方での制度運用実態 一, 日本建築学会計画系論文集, 第 605 号, pp135 142, 2006.7

3）千石達也, 松岡佳秀, 瀬戸口剛, 小林英嗣 : 都市と農村の共生を視点と した優良田園住宅制度の活用方策, 日本建築学会技術報告集, 第 14 号, pp275 278, 2001. 12

4）逢見まどか，東正則：優良田園住宅法における居住環境の実現促進に関 する研究: 上越市アーバンビレッジを例として, 農村計画論文集, 第 3 号, pp7 12, 2001. 12

5）清水郁江, 森傑 : 地域コミュニティのサステナビリティからみた優良田 園住宅の計画手法に関する課題考察 : 富山市田園住宅開ヶ丘事業のケース スタディを通して, 都市計画論文集, 第 43 (3) 号, pp 445 450, 2008.10

6）太田雅幸：ゆとりある田園居住の実現一優良田園住宅の建設の促進に関 寸る法律, 時の法令, 第 1589 号, pp 49〜56, 1999.3

7) 浅野純一郎: 都市計画法 34 条 11 号条例導入による効果と課題に関する 研究一-群馬県高崎市を対象として, 日本建築学会技術報告集, 第 16(32) 号, pp297-301, 2010.2

8) 馬相烈, 大貝彰 : 市街化調整区域における都市計画法 34 条 8 号の 3 の活 用および運用方針に関する考察：条例施行済 4 都市及び愛知県主要都市 を事例として, 日本建築学会計画系論文集, 第 575 号, pp85-91, 2004.1

9）塚本 太一, 和多治: 地方中心都市での改正都市計画法の運用に関する調 查研究-一市街化調整区域での開発許可条例による開発コントロールを中心 に, 都市計画論文集, 第 40 号, pp403-408, 2005.10

10）松浦貴, 中出文平 : 地方都市の市街化調整区域における開発の実態と課 題に関する研究, 都市計画論文集, 第 37 号, pp685-690, 2002.10

11) 内田一平, 中出文平 : 地方都市計画区域における区域区分制度運用に関 寸る研究，都市計画論文集，第 33 号, pp505-510, 1998.10

12）浅野純一郎：地区計画による市街化調整区域の土地利用マネジメント手 法の検証--福岡県久山町を対象として, 都市計画論文集, 第 44 号, pp $643-648,2009.10$ 